\title{
PARP-1 modulates B1-integrin/NF-kB-mediated radioresistance in human breast cancer
}

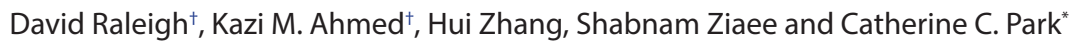

*Correspondence: catherine.park@ucsf.edu

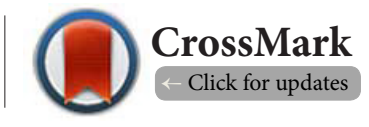

${ }^{\dagger}$ These authors contributed equally to this work.

Department of Radiation Oncology, University of California, San Francisco, CA, USA.

\begin{abstract}
Genomic damage triggers a signal transduction network that modulates gene expression and protein stability to repair DNA and influence cell survival. Inhibition of the DNA damage response protein PARP1 is the subject of ongoing preclinical and clinical investigations in breast cancer, where DNA damage activates protective signaling networks that are transmitted through the extracellular matrix by the transmembrane protein $\beta$-integrin. $\beta 1$-integrin influences gene expression by modulating activity of the transcription factor $\mathrm{NF}-\kappa \mathrm{B}$, yet the mechanism by which DNA damage activates $\beta 1$-integrin is unknown. Here we demonstrate that breast cancer cells are enriched in PARP-1, and that PARP-1 activity is required for signaling through the tumor microenvironment in response to ionizing radiation. Moreover, PARP1 and $\beta$ 1-integrin cooperatively regulate viability and growth of breast cancer cells propagated in three dimensional laminin-rich extracellular matrix (3D lrECM) cultures. Finally, we show that PARP-1 interacts with both $\beta$ 1-integrin and $\mathrm{NF}-\kappa \mathrm{B}$ in response to genotoxic stress to link signaling through the extracellular matrix to changes in gene expression. The data are consistent with a model whereby PARP-1 inhibition sensitizes cancer cells to the cytotoxic effects of DNA damage by coordinated disruption of both tumor microenvironment- and NF- $\kappa \mathrm{B}$-signaling pathways.
\end{abstract}

Keywords: Breast cancer, tumor microenvironment, PARP-1, $\beta 1$-integrin, NF- $\kappa \mathrm{B}$

\section{Introduction}

Tumor cell interaction with the extracellular matrix is a significant source of acquired or developed cancer therapy resistance in human cancers $[1,2]$. These signals are transduced by integrins, a large family of transmembrane glycoproteins that are phosphorylated to regulate diverse cellular processes [3]. In breast carcinoma, $\beta 1$-integrins are aberrantly expressed to influence cell fate, organization, survival, apoptosis, and acquired resistance to human epidermal growth factor inhibitor [4-6]. Indeed, $\beta 1$-integrin expression is predictive for both death and development of metastatic disease in human breast cancer patients, and has therefore garnered considerable interest as a target for molecular therapeutics in recent years $[7,8]$.

We recently demonstrated that $\beta 1$-integrin promotes both invasiveness and radioresistance through cooperative signaling with the ubiquitous transcription factor nuclear factor K-lightchain enhancer of activated B cells (NF-KB) $[9,10]$. Mammalian $\mathrm{NF}-\mathrm{KB}$ is a dimer composed of varying subunits depending on the cellular context, including p50, p52, p65 (RelA), c-Rel, and
RelB. Activation of NF-KB signaling occurs upon degradation of inhibitor- $\mathrm{KB}$ (IKB) proteins, which allows NF-KB to translocate from the cytoplasm to the nucleus and bind specific $K B$-sites to regulate gene expression (www.NF-KB.org) $[\mathbf{1}, \mathbf{1 1}]$.

The DNA damage response (DDR) is an evolutionarily conserved signal transduction network that has been implicated in NF-KB activation [12-15]. In BRCA-deficient breast cancer, small molecular inhibitors of the DNA-dependent nuclear enzyme poly(ADP-ribose) polymerase (PARP) lead to synthetic lethality and are the subject of ongoing preclinical and clinical investigation as radiosensitizers and adjuvant therapies $[7,16,17]$. PARP-1 plays a pivotal role in the DDR, and also modulates angiogenesis, metastasis, metabolism, survival, chromatin structure, and NF-KB-mediated tumor inflammation $[9,10,18,19]$. In particular, PARP-1 interacts with NF-KB independent of DNA binding or PARP-1 enzymatic activity to regulate signaling through the TME by activating fibronectin (FN1) and intercellular adhesion molecule 1 (ICAM-1) transcription [20-23]. Moreover, PARP-1 mediates radioresistance in response to ion- 
izing radiation-induced NF- $\mathrm{kB}$ activation without influencing IkBa degradation or nuclear translocation of p50 or p65 [24].

Given the parallels between the PARP-1, NF-KB and $\beta 1$ integrin activity in response to DNA damage, we hypothesized that PARP-1 connects TME and NF-KB signaling pathways to regulate cellular radioresistance. The data demonstrate that PARP-1 interacts with both $\beta 1$-integrin and NF- $\mathrm{KB}$, and that PARP-1 inhibition attenuates TME- and NF-KB-signaling to sensitize tumor cells to the cytotoxic effects of ionizing radiation. The heretofore-unidentified mechanist connection between PARP-1 and $\beta 1$-integrin signaling in breast cancer suggests that PARP-1 inhibition disrupts both TME and NF-KB signaling to sensitize human malignancies to DNA damage.

\section{Materials and methods \\ Cell culture}

Non-malignant S1 and malignant T4-2 human breast cancer cells were maintained as described previously [25]. For experimentation, S1 and T4-2 cells in complete media were seeded as single cells in three-dimensional (3D) laminin-rich extracellular matrix (IrECM) (Matrigel, Trevigen, MD). For experiments involving the PARP inhibitor AG-14361 (Selleckchem, Houston, TX), drug or vehicle control was added after 4 or 6 days for T4-2 and S1 cells, respectively (Figure 1A). After 24 hours of exposure, cells were radiated and collected for analysis at the indicated time points $[\mathbf{2 6}, \mathbf{2 7}]$.

\section{Electrophoretic mobility shift assay (EMSA)}

Cells in 3D IrECM cultures were harvested using the nuclear extraction kit (Thermo Scientific, Rockford, IL) following the manufacturer's specifications. Protein concentration was determined using the DC Protein Quantitation Kit (Bio-Rad, Hercules, CA), and NF-KB DNA binding activity was quantified using the TransAM ${ }^{\mathrm{TM}}$ NF-KB TF assay kit (Active Motif, Carlsbad, CA). In brief, $10 \mu \mathrm{g}$ of nuclear extract in cell binding and cell lysis buffer were added in each well in streptavidin-coated 96-microtiter plates in triplicate. Nuclear extract from the Burkitt's lymphoma Raji cell line was used a positive control. Oligonucleotides containing a $10 \mathrm{bp}$ NF-KB binding motif (wild type or mutated) from the human $\beta 1$-integrin promoter were custom synthesized and biotinylated (Midland Certified Reagent Company, Midland, TX). Excess wild-type NF-kB consensus oligonucleotide (20 pmol/well) or an inactive mutated consensus oligonucleotide was added to nuclear extracts. After washing, wells were sequentially incubated with a primary antibody against p65 NF-kB (Cell Signaling), followed by anti-rabbit peroxidase-conjugated antibody (GE Health Care, United Kingdom). After substrate addition, peroxidase activity was measured by reading $450 \mathrm{~nm}$ in a SpectraMax ${ }^{\circledR}$ Microplate Spectrophotometer (Molecular Devices, Sunnyvale, CA).

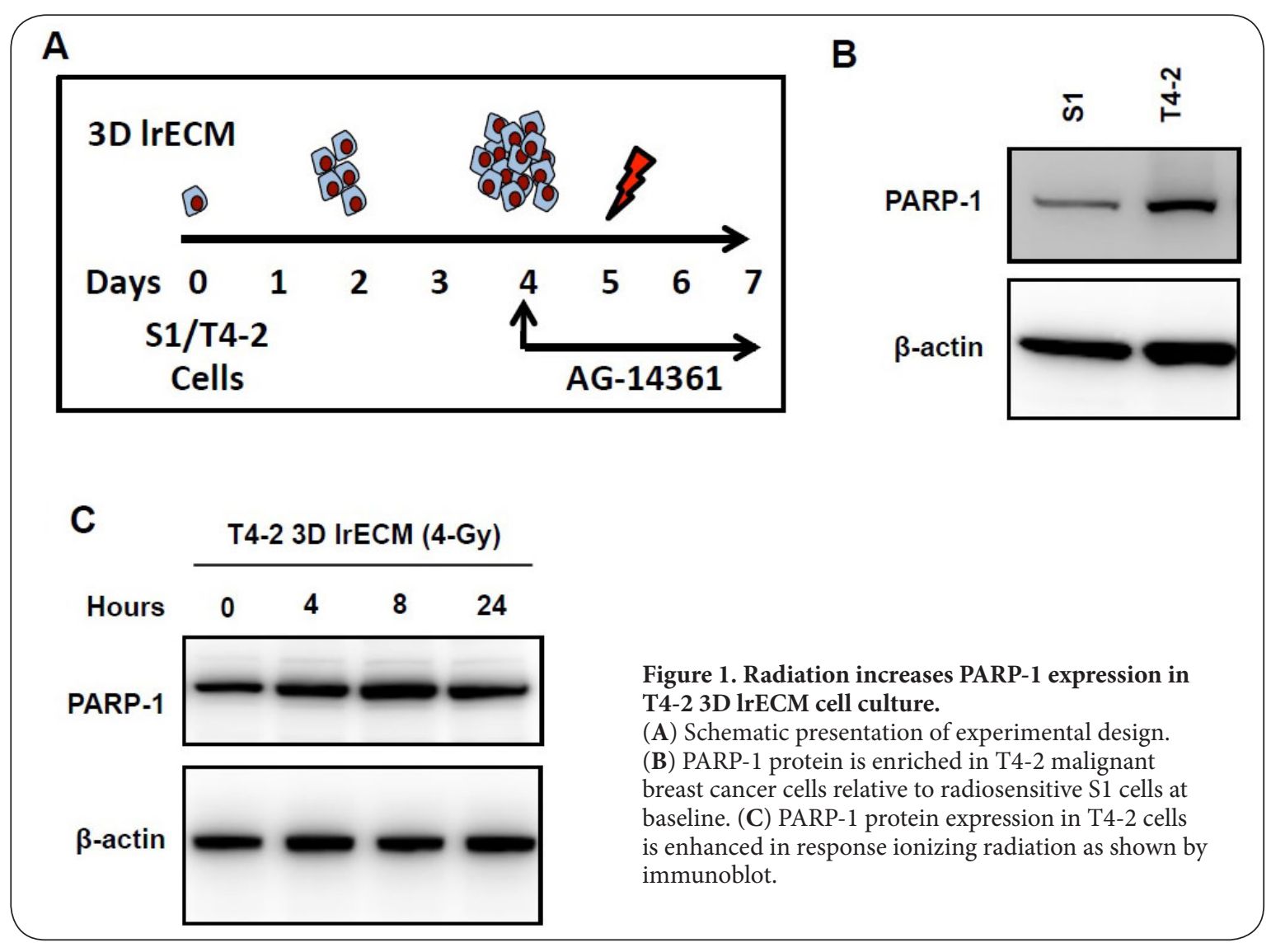




\section{Immunoblotting}

Cells grown in 3DIrECM were extracted using ice-cold PBS $(\mathrm{pH}$ 7.2) containing $5 \mathrm{mM}$ EDTA, and lysed in radioimmunoprecipitation assay (RIPA) buffer as described previously [25]. After protein quantification using the DC Protein Quantitation Kit (Bio-Rad), equal amounts of protein were loaded onto sodium dodecyl sulfate gels (Invitrogen, Carlsbad, CA). After polyacrylamide gel electrophoresis, samples were transferred onto PVDF membrane (Millipore, Temecula, CA) and blocked with $5 \%$ nonfat milk before incubation with antibodies. Lastly, blots were visualized using the ECL Western blotting detection system (Thermo Scientific). The following primary antibodies were used: PARP-1 (Calbiochem, CA); $\beta 1$-integrin, clone 18 (BD Transduction Laboratories, Lexington, KY); phospho$\beta 1$-integrin (Biosource International, Camarillo, CA); FAK (BD Transduction, San Jose, CA); pFAK (BD Transduction); cleaved caspase 3 (Cell Signaling, Beverly, MA); and $\beta$-actin (Sigma, St. Louis, MO). Densitometry was performed using Image J software, and expression was normalized against either $\beta$-actin or unphosphorylated cognate protein.

\section{Immunoprecipitation}

Protein was extracted using lysis buffer at $4^{\circ} \mathrm{C}$ containing 1\% Brij 98, $150 \mathrm{mM} \mathrm{NaCl}, 25 \mathrm{mM}$ HEPES, $5 \mathrm{mM} \mathrm{MgCl} 2$ and $1 \%$ eukaryotic proteinase inhibitor cocktail (Calbiochem). Extracts were pre-cleared for $1 \mathrm{hr}$ with normal rat immunoglobulin $\mathrm{G}$ and $25 \mu$ l of Dynabeads ${ }^{\circledR}$ protein $\mathrm{G}$ (Invitrogen) at $4^{\circ} \mathrm{C}$, and then incubated overnight at $4^{\circ} \mathrm{C}$ with anti-PARP or anti- $\beta 1$-integrin antibodies (Argon Bioscience, Morgan Hill, CA). Immuno complexes were captured by an additional 1 hour incubation with $25 \mu$ l of Dynabeads ${ }^{\circledR}$ protein G. Lastly, beads were collected, washed, and prepared for analysis on 4-20\% Novex ${ }^{\circledR}$ Tris-Glycine gels (Invitrogen).

\section{Proliferation and apoptosis assays}

Terminal deoxynucleotidyl transferase-mediated dUTP nick end labeling (TUNEL) was used for apoptosis detection [28]. In brief, T4-2 3D IrECM cell cultures were collected on day 7, fixed onto glass slides in 4\% paraformaldehyde, and permeabilized in $0.1 \%$ Triton $\mathrm{X}-100$ in $0.1 \%$ sodium citrate. Samples were then washing and incubated in TUNEL reaction mixture (In Situ Cell Death Detection Kit, Roche) at $37^{\circ} \mathrm{C}$ for $1 \mathrm{hr}$. Cells were counterstained with 4,6-diamino-2-phenylindole (DAPI) at room temperature for $5 \mathrm{~min}$, washed and mounted. Fluorescent images were captured using a ZEISS microscopy equipped with an AxioCam HRm camera.

Ki-67 nuclear antigen (Novocastra Laboratories, Norwell, MA) was used to stain cells for immunofluorescence. In brief, samples were fixed in methanol/acetone, blocked using $10 \%$ goat serum in IF buffer $(0.05 \%$ NaN3, $0.1 \%$ BSA, $0.2 \%$ Triton-X 100 and $0.05 \%$ Tween 20 in PBS) and treated with 1:250 dilution of goat anti-mouse IgG Fab fragments (Life Technology, Carlsbad, CA). Samples were incubated overnight at $4{ }^{\circ} \mathrm{C}$ with $\mathrm{Ki}-67$ antibodies, washed, and then treated with
FITC-conjugated anti-rabbit secondary antibodies (Jackson Laboratory, Bar Harbor, ME). Nuclei were counterstained with DAPI, and images were again captured using a ZEISS microscopy equipped with an AxioCam HRm camera.

RNA isolation and quantitative real-time PCR (qRT-PCR) 3D IrECM cell cultures were extracted as described above, and RNA was purified using the Qiagen RNeasy kit according to the manufacturer's instructions (Qiagen, Venlo, Limburg). The M-MLVkit was used for reverse transcription of $1.5 \mu \mathrm{g}$ of each sample (Invitrogen). qRT-PCR was carried out using 2 $\mu$ l of cDNA from each sample with the SYBR ${ }^{\circ}$ Green PCR Kit (Invitrogen). Samples were amplified and analyzed using Step One Software v2.3 (Applied Biosystems, Carlsbad, CA) at $95^{\circ} \mathrm{C}$ for $10 \mathrm{~min}$, followed by 40 amplification cycles of $94^{\circ} \mathrm{C}$ for $15 \mathrm{~s}$ followed by $60^{\circ} \mathrm{C}$ for $60 \mathrm{~s}$. Primer sequences are as follow; $\beta 1$-integrin (forward: 5'-AGGTGGTTTCGATGCCATCAT-3', 5'-AAGTGAAACCCGGCATCTGTG-3') and GAPDH (forward: 5'-AGCCACATCGCTCAGACA-3', reverse: 5'-GCCCAATACGACCAAATCC-3').

\section{Statistics}

Unpaired, two-tailed Student's t-test were used to compare groups, and statistical significance was defined as $\mathrm{P}<0.05\left(^{*}\right)$. Unless specified otherwise, data are displayed as the average value of at least 3 biologic replicates \pm standard deviation, and are representative of at least 2 independent experiments.

\section{Results}

We have previously shown that NF-KB and $\beta 1$-integrin cooperate to enhance radioresistance in breast cancer cell culture through a feed forward mechanism [9]. We therefore sought to determine if DDR effectors orchestrate $\beta 1$-integrin/NF-kB signaling to protect tumor cells from DNA damage-induced cytotoxicity. To do so, T4-2 breast cancer cells were grown in 3D IrECM, which better mimics physiologic growth conditions and interactions with the TME than 2D culture. When grown in 3D conditions, T4-2 cell cultures are enriched in PARP-1 relative to nonmalignant S1 acinar structures (Figure 1B). Moreover, PARP-1expression is intensified in T4-2 3D IrECM colonies following ionizing radiation, but does not significantly change in S1 cells in response to DNA damage (Figure 1C, Supplementary Figure 1).

Disruption of $\beta 1$-integrin interactions with the TME promotes apoptosis in malignant cells and heightens the cytotoxic effects of radiation [29,30]. To determine if PARP-1 modulates $\beta 1$-integrin mediated signaling in response to DNA damage, T4-2 colonies were treated with AG14361, a potent small molecule inhibitor of PARP-1, and protein lysates were assessed by immunoblot [31]. The data demonstrate that PARP-1 inhibition not only blocks changes in the level and phosphorylation of $\beta 1$-integrin after ionizing radiation, but also decreases the amount of phospho (T788/789) $\beta 1$-integrin at baseline (Figure 2A, Supplementary Figure 2A). Consistently, 


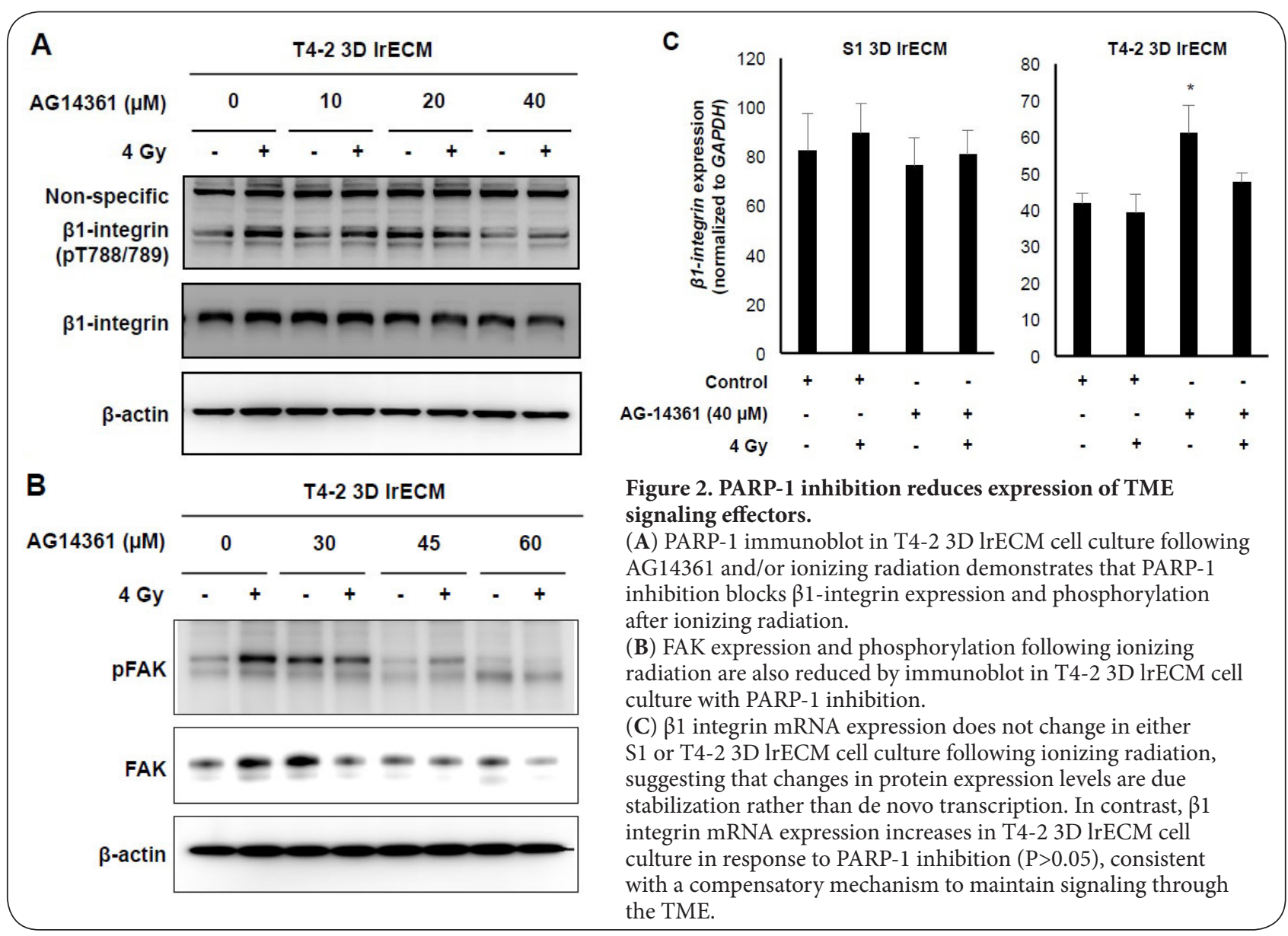

PARP-1 inhibition attenuates the expression and irradiationinduced phosphorylation of focal adhesion kinase (FAK), a cytosolic tyrosine kinase involved in the transduction of diverse signals in response to integrin engagement (Figure 2B, Supplementary Figure 2B) [32]. qRT-PCR assessment of transcript levels suggests that these findings are not the result of changes inprotein synthesis, but rather the product of altered protein stability. In this regard, ionizing radiation fails to alter $\beta 1$-integrin mRNA expression in either S1 or T4-2 colonies (Figure $\mathbf{2 C}$ ).

Given the importance of PARP-1 activity for integrinmediated signaling, we next investigated the effect of PARP-1 inhibition on breast cancer organoid growth and proliferation. T4-2 3D IrECM colonies were treated with AG14361 or vehicle control with or without irradiation, and imaged (Figure $3 A$ ). Both PARP- 1 blockade and the $\beta 1$-integrin inhibitory antibody ABII2 significantly reduced acinar diameter (Figure 3B). The addition of ionizing irradiation further reduced organoid growth, although the magnitude of effect was blunted relative to either PARP-1 or $\beta 1$-integrin inhibition alone. Similarly, PARP1 and $\beta 1$-integrin inhibition increased apoptosis (Figure $3 \mathrm{C}$ ) and reduced cell proliferation (Figure 3D), the effect of each was synergistically amplified with ionizing radiation (Figure 3C).
Consistent with these data, PARP-1 inhibition increased the level of cleaved caspase- 3 both at baseline and in response to irradiation (Figure 3E). Together, these data demonstrate that coordinated PARP-1/ $\beta 1$-integrin signaling attenuates apoptosis in response to DNA damage to regulate tumor cell proliferation and radioresistance.

To determine if PARP- 1 acts directly on $\beta 1$-integrin to regulate cell viability in response to DNA damage, reciprocal immunoprecipitation experiments were performed from T4-2 and S1 3D IrECM cell cultures. These experiments show that $\beta 1$-integrin interaction with PARP-1 significantly increases in response ionizing radiation (Figure 4A). However, following PARP- 1 inhibition with AG14361, $\beta 1$-integrin recovery is comparable to background in both $\mathrm{S} 1$ and T4-2 cell lysates. Consistently, PARP- 1 recovery fromT4- 2 anti- $\beta 1$-integrin immunoprecipitates is radiation-dependent, and attenuates in the presence of AG14361 (Figure 4B). In combination with quantitative immunoblots, cell proliferation studies, and apoptosis assays, these protein binding data demonstrate that interaction with PARP-1 regulates $\beta 1$-integrin expression and activity to modulate radioresistance following DNA damage.

NF-KB p65 regulates invasiveness and radioresistance of breast cancer cells in response to $\beta 1$-integrin signaling $[9,33]$. 


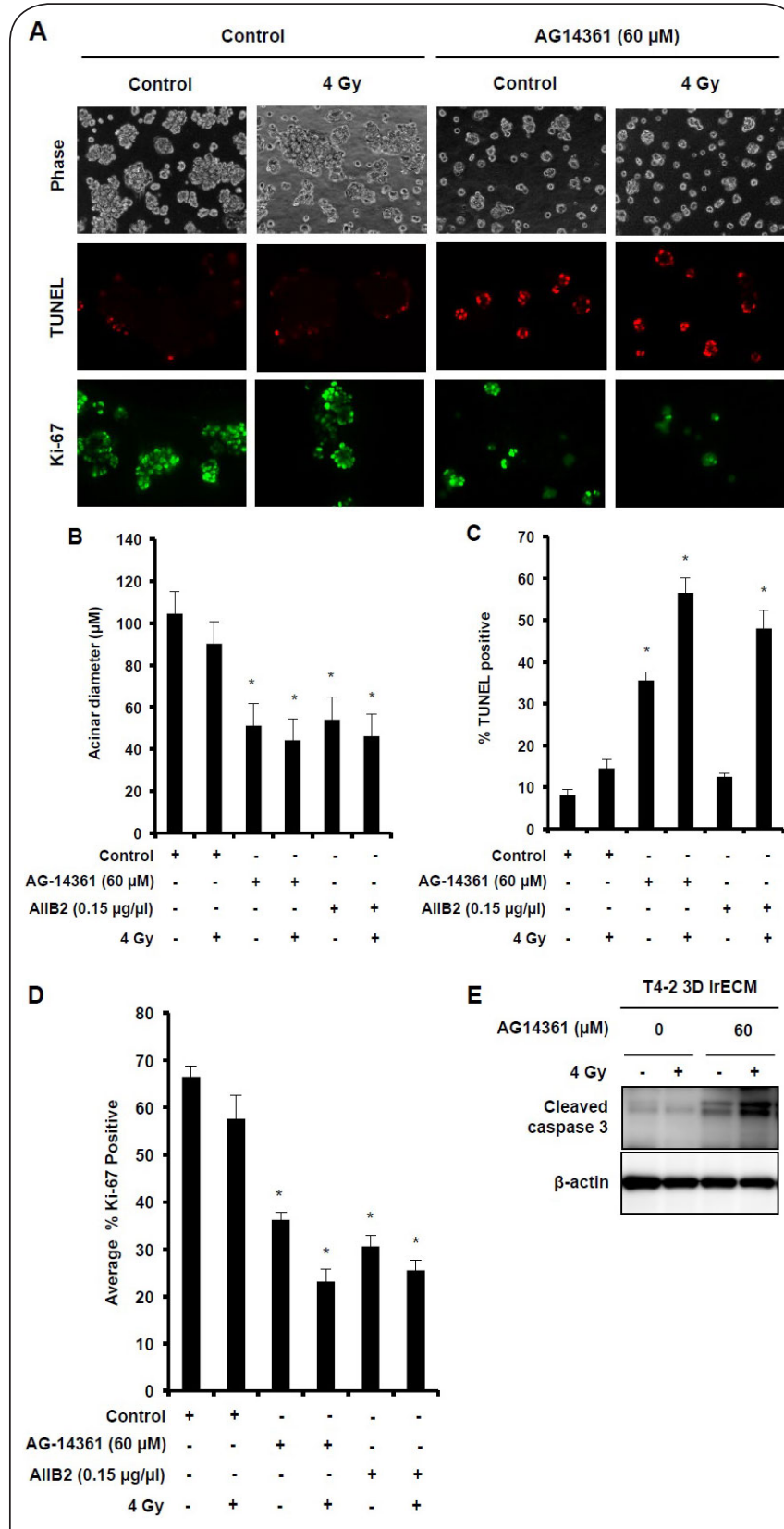

Figure 3. PARP-1- and $\beta 1$-integrin-signaling attenuate apoptosis to regulate tumor cell proliferation and radioresistance.

(A) Morphology, TUNEL and Ki-67 staining of T4-2 3D lrECM cell culture with or without AG14361 and/ orirradiation.

(B) Morphometric quantification of T4-2 acinar diameter demonstrates that PARP-1 and $\beta 1$-integrin inhibition impairs cell growth.

(C) TUNEL assay shows increased T4-2 cell death when either PARP-1 or $\beta 1$-integrin inhibition is combined with radiation. (D)Ki-67 staining confirms that T4-2 proliferation is lowest when either PARP-1 or $\beta 1$-integrin inhibition is combined with radiation.

(E) Quantitative immunoblots demonstrate that expression of cleaved caspase 3 is increased with PARP-1 inhibition alone, and further increases with the addition of radiation.

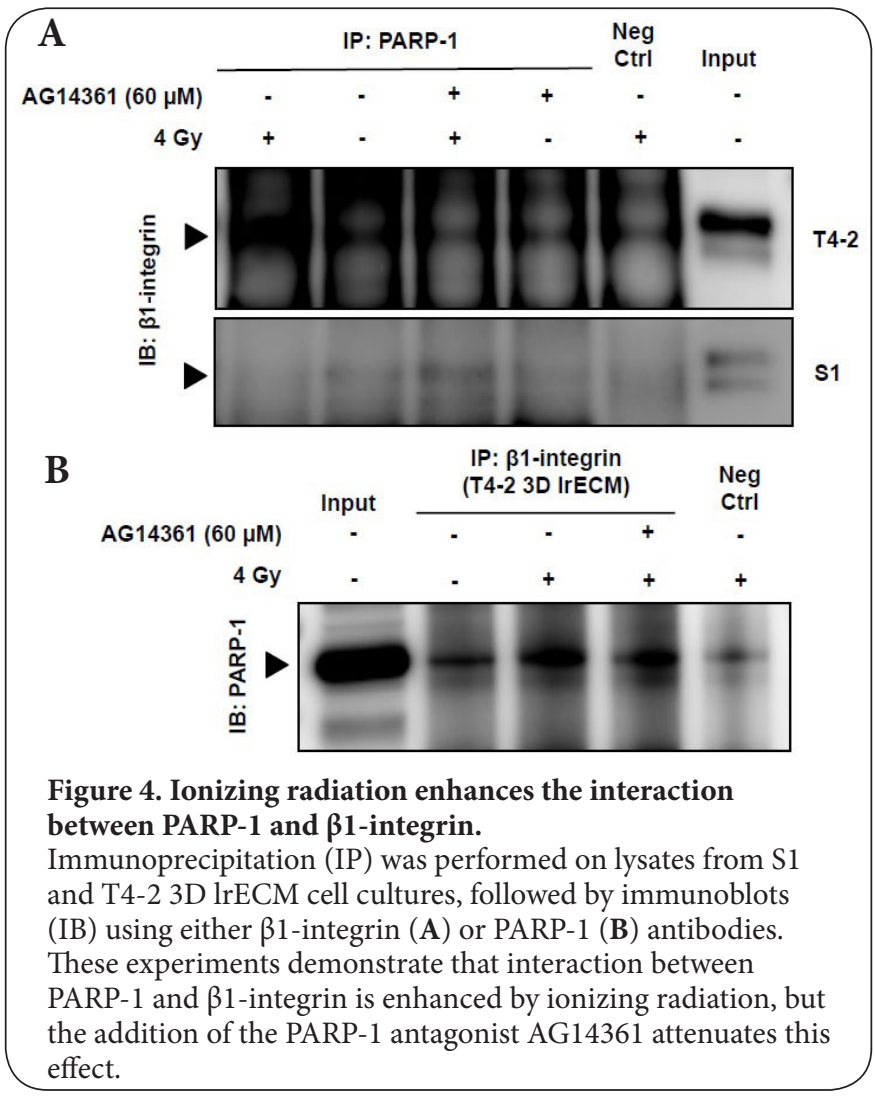

In this pathway, NF-KB also binds to the promoter region of $\beta 1$-integrin to modulate integrin expression and extracellular matrix signaling through a feed forward mechanism. Given that PARP- 1 was found to influence $\beta 1$-integrin signaling in response to DNA damage, we sought to determine if PARP-1 also modulates NF-KB activity. EMSA with oligonucleotides containing wild type or mutated $\mathrm{KB}$ binding sites was therefore performed from T4-2 3D IrECM nuclear extracts in the presence or absence of AG14361. These experiments demonstrate that PARP-1 inhibition attenuates radiation-induced p65 DNA binding (Figure 5A). This effect appears to be mediated through interaction between PARP-1 andNF-KB, as p65 is enriched in T4-2 3D IrECM anti-PARP-1 immunoprecipitates following ionizing radiation, but diminished upon addition of AG14361 (Figure 5B). In sum, the data support a model whereby PARP-1 links $\beta 1$ integrin signaling in response to DNA damage to the NF-KB transcriptional program to modulate the cellular response to ionizing radiation.

\section{Discussion}

PARP-1 regulates NF-KB activation by multiple mechanisms, which vary not only according to PAR acceptor protein, but also NF-KB subunit identity and signalosome composition [19]. Here we demonstrate that PARP-1 regulates both TME- and NF-KB signaling in response to DNA damage to promote tumor cell survival in a $3 \mathrm{D}$ in vitro model of breast 


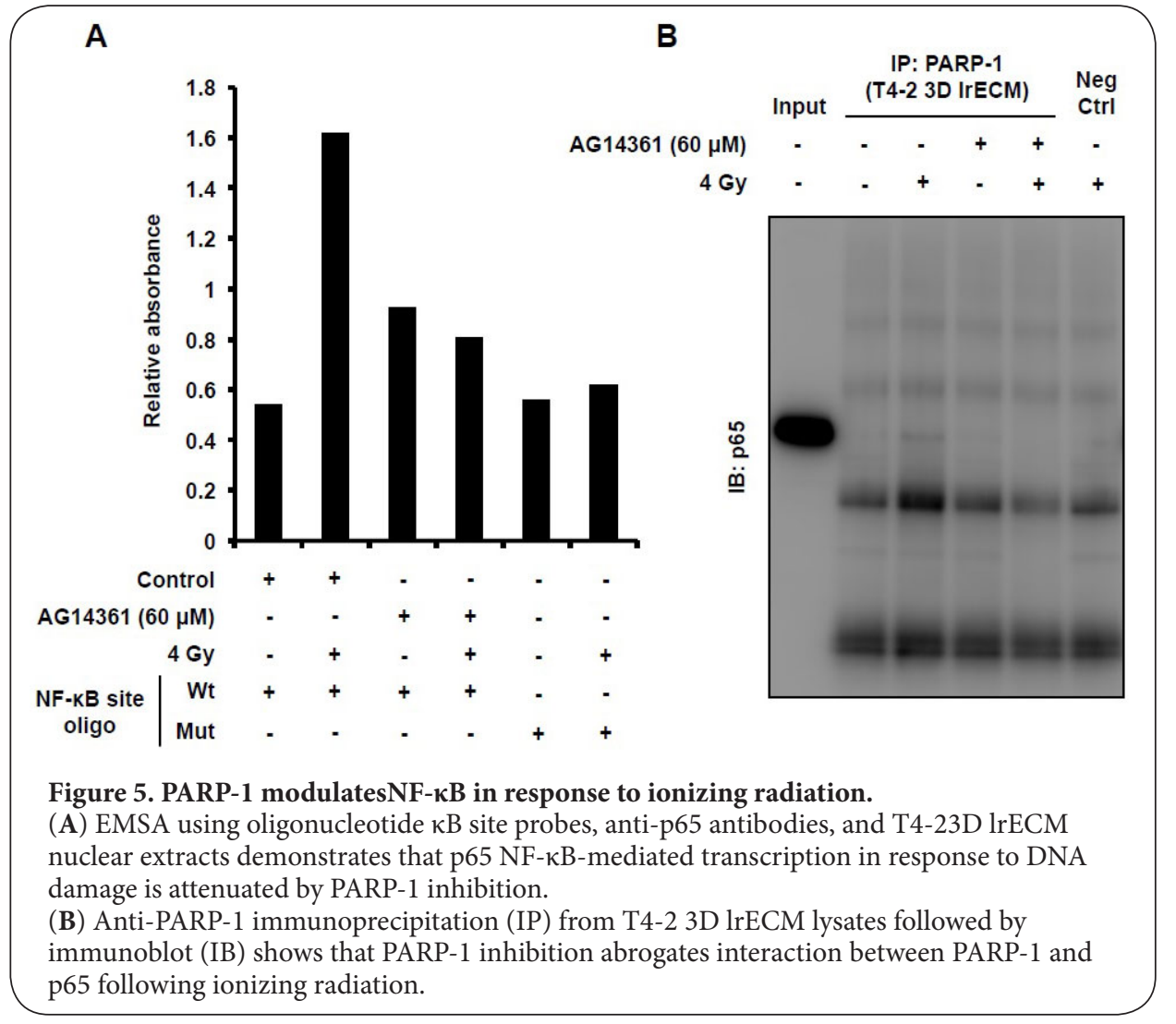

cancer. In this model, targeted agents against either PARP1 or $\beta 1$-integrin promote apoptosis and impair tumor cell survival and growth after ionizing radiation. These effects appear to be mediated by interaction between PARP-1 and $\beta 1$-integrin, and also between PARP-1 and NF-KB. It remains to be established if $\beta 1$-integrin, either in its full-length form or after proteolytic processing, also interacts with NF-KB to modulate transcriptional behavior in response to ionizing radiation. Moreover, it is unclear if such an interaction would be a relevant therapeutic target in combination with PARP-1 inhibition. The majority of combination molecular therapies have proven to be overly toxic in most human trials to date, and ongoing investigation is required to identify new means of achieving synthetic lethality. In the interim, the data presented here warrant investigation of combined PARP-1 and $\beta 1$-integrin antagonism within in vivo breast cancer models.

Consistent with the observation that many cancers display misregulation of the DDR, PARP-1 protein expression is elevated in breast cancer cells relative to wild type mammary epithelia both at baseline and in response to DNA damage [16]. Although specific DDR defects have not been identified for the majority of malignancies, the data presented here illustrate that PARP-1 exerts a pro-survival effect in breast cancer that is independent from its function as a DNA repair enzyme [34]. Thus, traditional assays for evaluating the fidelity of DNA repair may overlook many non-canonical effects of mutated or misregulated DDR proteins in human malignancies. Indeed, evolving understanding of the molecular connections between the DDR and other pro-survival cellular pathways in human cancers is likely to identify additional targets for therapeutic intervention.

Our data demonstrate that PARP-1 connects the DDR and NF-KB-mediated transcription to pro-survival signaling through the TME. The role of NF-KB in the DDR is complex, and both the activation and behavior of NF-KB appear to depend on the type of genomic lesion and cellular context in which the damage occurs [13]. We previously reported that radiationinduced $\beta 1$-integrin expression in human breast cancer cells was mediated by NF-KB [9]. In support a functional connection between TME, NF-KB, and DDR signaling, we observed an increase in $\beta 1$-integrin transcript levels following PARP-1 inhibition in breast cancer cells. This observation is consistent with a compensatory mechanism to maintain a homeostatic signaling balance between the TME and DDR in malignancy, but it is notable that a similar response was not seen in non-malignant cell culture. The data presented here do not establish a definitive connection between heightened TME signaling and malignancy, but the discrepancy in $\beta 1$-integrin transcription following PARP-1 inhibition is certainly consistent with such a model.

\section{Conclusion}

Our data demonstrate that a functional link exists between 
PARP-1 activity in response to DNA damage, pro-growth signals through the TME, and NF-KB-mediated transcription in human breast cancer cell culture. These datashed light onto the process by which PARP-1 inhibition sensitizes breast cancer cells to genotoxic therapies, and serve as a rational for pre-clinical studies of combination PARP- 1 and $\beta 1$-integrin inhibitors within in vivo breast cancer models.

\section{Additional files}

\section{Supplementary Figure S1 \\ Supplementary Figure S2}

Competing interests

The authors declare that they have no competing interests.

Authors' contributions

\begin{tabular}{|l|c|c|c|c|c|}
\hline Authors' contributions & DR & KMA & HZ & SZ & CCP \\
\hline Research concept and design & $\checkmark$ & $\checkmark$ & $\checkmark$ & $\checkmark$ & $\checkmark$ \\
\hline Collection and/or assembly of data & $\checkmark$ & $\checkmark$ & $\checkmark$ & $\checkmark$ & $\checkmark$ \\
\hline Data analysis and interpretation & $\checkmark$ & $\checkmark$ & -- & $\checkmark$ & $\checkmark$ \\
\hline Writing the article & $\checkmark$ & -- & -- & $\checkmark$ & $\checkmark$ \\
\hline Critical revision of the article & $\checkmark$ & -- & -- & $\checkmark$ & $\checkmark$ \\
\hline Final approval of article & $\checkmark$ & -- & -- & $\checkmark$ & $\checkmark$ \\
\hline Statistical analysis & $\checkmark$ & -- & -- & $\checkmark$ & $\checkmark$ \\
\hline
\end{tabular}

\section{Acknowledgement}

CCP supported by National Institutes of Health, R01CA124891 and R01 CA174929; KMA supported by National Institutes of Health, R01CA124891.

Publication history

Senior Editor: Jiaoti Huang, Duke University School of Medicine, USA. EIC: G. J. Peters, VU University Medical Center, Netherlands.

Received: 01-Dec-2015 Final Revised: 19-Jan-2016

Accepted: 04-Feb-2016 Published: 12-Feb-2016

\section{References}

1. Baumann $M$, Krause $M$ and Hill R. Exploring the role of cancer stem cells in radioresistance. Nat Rev Cancer. 2008; 8:545-54. | Article | PubMed

2. Hanahan $D$ and Weinberg RA. Hallmarks of cancer: the next generation. Cell. 2011; 144:646-74. | Article | PubMed

3. Giancotti FG and Ruoslahti E. Integrin signaling. Science. 1999; 285:102832. | Article | PubMed

4. Shaw LM. Integrin function in breast carcinoma progression. J Mammary Gland Biol Neoplasia. 1999; 4:367-76. | Article | PubMed

5. Brakebusch $C$ and Fassler $R$. The integrin-actin connection, an eternal love affair. EMBO J. 2003; 22:2324-33. | Article | PubMed Abstract | PubMed FullText

6. Huang C, Park CC, Hilsenbeck SG, Ward R, Rimawi MF, Wang YC, Shou $\mathrm{J}$, Bissell MJ, Osborne CK and Schiff R. beta1 integrin mediates an alternative survival pathway in breast cancer cells resistant to lapatinib. Breast Cancer Res. 2011; 13:R84. | Article | PubMed Abstract | PubMed FullText

7. Cordes $\mathrm{N}$ and Park $\mathrm{CC}$. beta1 integrin as a molecular therapeutic target. Int J Radiat Biol. 2007; 83:753-60. | Article | PubMed

8. Yao ES, Zhang H, Chen YY, Lee B, Chew K, Moore D and Park C. Increased beta1 integrin is associated with decreased survival in invasive breast cancer. Cancer Res. 2007; 67:659-64. | Article | PubMed
9. Ahmed $\mathrm{KM}$, Zhang $\mathrm{H}$ and Park CC. NF-kappaB regulates radioresistance mediated by beta1-integrin in three-dimensional culture of breast cancer cells. Cancer Res. 2013; 73:3737-48. | Article | PubMed Abstract I PubMed FullText

10. Nam JM, Chung Y, Hsu HC and Park CC. beta1 integrin targeting to enhance radiation therapy. Int J Radiat Biol. 2009; 85:923-8. | Article | PubMed

11. Vallabhapurapu $S$ and Karin M. Regulation and function of NF-kappaB transcription factors in the immune system. Annu Rev Immunol. 2009; 27:693-733. | Article | PubMed

12. Campbell KJ, Witty JM, Rocha S and Perkins ND. Cisplatin mimics ARF tumor suppressor regulation of RelA (p65) nuclear factor-kappaB transactivation. Cancer Res. 2006; 66:929-35. | Article | PubMed

13. Wu ZH and Miyamoto $\mathrm{S}$. Many faces of NF-kappaB signaling induced by genotoxic stress. J Mol Med (Berl). 2007; 85:1187-202. | Article | PubMed

14. Yamini B, Yu X, Dolan ME, Wu MH, Darga TE, Kufe DW and Weichselbaum RR. Inhibition of nuclear factor-kappaB activity by temozolomide involves 06-methylguanine induced inhibition of p65 DNA binding. Cancer Res. 2007; 67:6889-98. | Article | PubMed

15. Schmitt AM, Crawley CD, Kang S, Raleigh DR, Yu X, Wahlstrom JS, Voce DJ, Darga TE, Weichselbaum RR and Yamini B. p50 (NF-kappaB1) is an effector protein in the cytotoxic response to DNA methylation damage. Mol Cell. 2011; 44:785-96. | Article | PubMed Abstract | PubMed FullText

16. Lord $\mathrm{CJ}$ and Ashworth A. The DNA damage response and cancer therapy. Nature. 2012; 481:287-94. | Article | PubMed

17. dos Santos PB, Zanetti JS, Ribeiro-Silva A and Beltrao El. Beta 1 integrin predicts survival in breast cancer: a clinicopathological and immunohistochemical study. Diagn Pathol. 2012; 7:104. | Article | PubMed Abstract | PubMed FullText

18. Sousa FG, Matuo R, Soares DG, Escargueil AE, Henriques JA, Larsen AK and Saffi J. PARPs and the DNA damage response. Carcinogenesis. 2012; 33:1433-40. | Article | PubMed

19. Weaver AN and Yang ES. Beyond DNA Repair: Additional Functions of PARP-1 in Cancer. Front Oncol. 2013; 3:290. | Article | PubMed Abstract I PubMed FullText

20. Hassa PO and Hottiger MO. A role of poly (ADP-ribose) polymerase in NF-kappaB transcriptional activation. Biol Chem. 1999; 380:953-9. | Article | PubMed

21. Hassa PO, Covic M, Hasan S, Imhof R and Hottiger MO. The enzymatic and DNA binding activity of PARP-1 are not required for NF-kappa B coactivator function. J Biol Chem. 2001; 276:45588-97. | Article | PubMed

22. Stanisavljevic J, Porta-de-la-Riva M, Batlle R, de Herreros AG and Baulida J. The $p 65$ subunit of NF-kappaB and PARP1 assist Snail1 in activating fibronectin transcription. J Cell Sci. 2011; 124:4161-71. | Article | PubMed

23. Zerfaoui M, Suzuki Y, Naura AS, Hans $C P$, Nichols $C$ and Boulares $A H$. Nuclear translocation of p 65 NF-kappaB is sufficient for VCAM-1, but not ICAM-1, expression in TNF-stimulated smooth muscle cells: Differential requirement for PARP-1 expression and interaction. Cell Signal. 2008; 20:186-94. | Article | PubMed Abstract | PubMed FullText

24. Veuger SJ, Hunter JE and Durkacz BW. lonizing radiation-induced NFkappaB activation requires PARP-1 function to confer radioresistance. Oncogene. 2009; 28:832-42. | Article | PubMed Abstract | PubMed FullText

25. Weaver VM, Petersen OW, Wang F, Larabell CA, Briand P, Damsky C and Bissell MJ. Reversion of the malignant phenotype of human breast cells in three-dimensional culture and in vivo by integrin blocking antibodies. J Cell Biol. 1997; 137:231-45. | Article | PubMed Abstract | PubMed FullText

26. Ahmed KM, Dong S, Fan M and Li JJ. Nuclear factor-kappaB p65 inhibits mitogen-activated protein kinase signaling pathway in radioresistant breast cancer cells. Mol Cancer Res. 2006; 4:945-55. | Article | PubMed

27. Guo G, Yan-Sanders Y, Lyn-Cook BD, Wang T, Tamae D, Ogi J, Khaletskiy 
A, Li Z, Weydert C, Longmate JA, Huang TT, Spitz DR, Oberley LW and Li JJ. Manganese superoxide dismutase-mediated gene expression in radiation-induced adaptive responses. Mol Cell Biol. 2003; 23:2362-78. | Article | PubMed Abstract | PubMed FullText

28. Park CC, Zhang H, Pallavicini M, Gray JW, Baehner F, Park CJ and Bissell MJ. Beta1 integrin inhibitory antibody induces apoptosis of breast cancer cells, inhibits growth, and distinguishes malignant from normal phenotype in three dimensional cultures and in vivo. Cancer Res. 2006; 66:1526-35. | Article | PubMed Abstract | PubMed FullText

29. Nam JM, Onodera Y, Bissell MJ and Park CC. Breast cancer cells in three-dimensional culture display an enhanced radioresponse after coordinate targeting of integrin alpha5beta1 and fibronectin. Cancer Res. 2010; 70:5238-48. | Article | PubMed Abstract | PubMed FullText

30. Eke I, Deuse Y, Hehlgans S, Gurtner K, Krause M, Baumann M, Shevchenko A, Sandfort V and Cordes N. beta(1)Integrin/FAK/cortactin signaling is essential for human head and neck cancer resistance to radiotherapy. J Clin Invest. 2012; 122:1529-40. | Article | PubMed Abstract | PubMed FullText

31. Calabrese CR, Almassy R, Barton $S$, Batey MA, Calvert AH, Canan-Koch S, Durkacz BW, Hostomsky Z, Kumpf RA, Kyle S, Li J, Maegley K, Newell DR, Notarianni E, Stratford IJ, Skalitzky D, Thomas HD, Wang LZ, Webber $\mathrm{SE}$, Williams KJ and Curtin NJ. Anticancer chemosensitization and radiosensitization by the novel poly(ADP-ribose) polymerase-1 inhibitor AG14361. J Nat/ Cancer Inst. 2004; 96:56-67. | Article | PubMed

32. Parsons JT. Focal adhesion kinase: the first ten years. J Cell Sci. 2003; 116:1409-16. | Article | PubMed

33. Nam JM, Ahmed KM, Costes S, Zhang $H$, Onodera $Y$, Olshen AB, Hatanaka KC, Kinoshita R, Ishikawa M, Sabe H, Shirato H and Park CC. beta1-Integrin via NF-kappaB signaling is essential for acquisition of invasiveness in a model of radiation treated in situ breast cancer. Breast Cancer Res. 2013; 15:R60. | Article | PubMed Abstract | PubMed FullText

34. Li M and Yu X. The role of poly(ADP-ribosyl)ation in DNA damage response and cancer chemotherapy. Oncogene. 2015; 34:3349-56. | Article | PubMed Abstract | PubMed FullText

Citation:

Raleigh D, Ahmed KM, Zhang H, Ziaee S and Park CC. PARP-1 modulates $\boldsymbol{\beta} 1$-integrin/NF- $\mathbf{B}$-mediated radioresistance in human breast cancer. $J$ Cancer Ther Res. 2016; 5:1. http://dx.doi.org/10.7243/2049-7962-5-1 